\title{
Antecedents That Influence the Intention to Use the Uber Mobile Application: Customer Perspectives in South Africa
}

\author{
https://doi.org/10.3991/ijim.v14i08.10632 \\ Eugine Tafadzwa Maziriri $\left({ }^{\square}\right)$ \\ University of the Free State, Bloemfontein, South Africa \\ maziririet@ufs.ac.za \\ Miston Mapuranga \\ The Da Vinci Institute for Technology Management, Johannesburg, South Africa \\ Justice Mushwana \\ Regenesys Business School, Johannesburg, South Africa \\ Nkosivile Welcome Madinga \\ University of Cape Town, Cape Town, South Africa
}

\begin{abstract}
In today's postmodern era there is a remarkable increase in the use of smartphones, GPS and the internet. This, in turn, has influenced businesses to adopt mobile commerce applications. The study sought to examine the impact of social influence, perceived convenience, facilitation conditions, and price value on the intention to the use the Uber application. A quantitative methodology was used and the research concentrated specifically on consumers located in the Johannesburg area. A self-administered data-gathering survey was used. In this research, Partial Least Squares-Structural Equation Modeling (PLS-SEM) was adopted as an approach to data analysis. The test results of the hypotheses showed that the intention to use the Uber application was substantially and positively affected by perceived convenience, facilitation conditions, social influence and price value. Ultimately, the shortcomings were discussed along with the guidelines and concluding remarks, based on the findings of this paper.
\end{abstract}

Keywords - Perceived convenience, facilitation conditions, social influence, price value on the intention to use the Uber application.

\section{Introduction}

In today's postmodern era, the prevalence of smart mobile devices is growing rapidly, reflecting a new generation of technical resources offering unparalleled access to content and creative usage opportunities [64]. In addition, mobile applications (apps) have changed the digital media landscape [66]. The understanding and rejuvenation of advanced technology has significantly changed consumers' needs and wishes [76]. 
Henceforth, [84] states that individuals have become accustomed to accepting data quickly and without constraints, wherever and whenever they need it. The spread of advanced technologies has made a difference in lifestyle, particularly for buyers' overall economic circumstances. This is particularly fundamental in the created world of sharing economies, where it is common for organisations to guide their business through online platforms. The sharing economy (defined as an economic system in which resources are exchanged among private individuals, free or at a cost, primarily through web methods [19]), depends on the rule that in a world with rare assets, it is frequently preferred to share rather than possess [57]. A good example - the car sharing company known as Uber - is a successful organisation within the sharing economy. Uber has been operating in South Africa for the last seven years, and has about 4000 drivers - more than $50 \%$ of whom operate in Gauteng $[55,26]$. Uber operates in major provinces of South Africa, namely: Gauteng, the Western Cape, KwaZulu-Natal, and the Eastern Cape (as shown by [20]).

Uber has limited urban proximity, meaning it favors mostly urban residents over rural residents. The current development of on-demand, application-based ride services has sparked a debate about their role in urban transport [69]. However, [ 66] reported that in May 2015, Uber showed that it would try different payment methods to make it easy for people without a bank account or credit cards to use the service. The purpose is to build interest in Uber and to increase its market share. It has had the ability to expand the number of publicly visible Uber drivers, which has reduced the financial benefits enjoyed by traditional metered cabs. In South Africa, Uber has been designated drop off zones by malls and airports. South African organisations have exploited open doors connected to Uber. [31] states that the vehicle loan provider, Wesbank, has introduced a car rent option for Uber drivers as they saw an opportunity to benefit from the ride share app. This implies Uber drivers can rent cars to use for their business through Wesbank.

It is also important to note that - given the extensive theoretical contributions made by various marketing scholars regarding Uber's advent and rise in the South African context - there seems to be a scarcity of South African research studies highlighting the impact of perceived convenience, facilitation conditions, social influence and price value on the intention to use the Uber mobile application. Previous researchers in South Africa have examined transport network companies such as Uber in various contexts by focusing on: South Africans' experience with the application [31]; a study looking at whether public transport is failing poor South Africans [71]; the impact of Uber in the South African economy [47]; an examination of the use of Uber by public transport users [58]; and how Uber has changed the public transportation system in South Africa [23]. Based on the above findings, the researcher is persuaded that there is a dearth of studies examining factors influencing the decision to use the Johannesburg Uber Mobile App. So, this supports the need for the present empirical study.

The next section discusses the review of the literature, followed by the creation of the conceptual model, and the hypotheses. These are then followed by a discussion on the methodology guiding the analysis, before the study results, explanations, consequences, suggestions and conclusions are presented in the last sections of the paper 


\section{Empirical Literature}

After a search on scholarly online databases and search engines, the literature was reviewed around the variables of this study. This section summarises literature on the research variables under investigation; namely perceived convenience, facilitating conditions, social influence, price value and intention to use Uber application.

\subsection{Perceived convenience}

As stated by [10], perceived convenience of the mobile application refers to the extent consumers think mobile applications are convenient for the efficient completion of a task. [56] further described perceived convenience as a degree of time, place and execution perceived when using the wireless network to complete a task. In their study entitled "perceived convenience in an extended technology acceptance model: mobile technology and English learning for college students". [11] described convenience perceived as the level of time, place and execution that one feels when engaging in mobile English learning. [27] emphasise that perceived convenience is a precedent affecting mobile technology.

\subsection{Facilitating conditions}

The term "facilitating conditions" refers to the degree to which a person feels that there is organizational and technical infrastructure to help use a program [65, 35]. Due to the availability and simplicity of conferring the demonstration, consumers would have standards that could easily be swayed, thereby forming more positive attitudes [45]. Moreover [12] and [45] noted that facilitation conditions had a positive impact on technology utilisation.

\subsection{Social influence}

[26] Suggested that social influence involves an endless cycle of exchanges that induce an individual's interest in representing themselves in a positive light to get approval from their social groups. Individuals tend to avoid anything that will attract disapproval from their social groups [27]. Generally, consumers tend to consider the views of their social groups before engaging in any behaviour including purchase behaviour [57]. It could be assumed that the social groups have an influence on the adoption of innovative products such as mobile applications.

\subsection{Price value}

The price value is defined as a cognitive comparison between the perceived benefits of mobile applications and the corresponding monetary costs in accordance with [51]. Individuals tend to be more price-sensitive compared to corporate clients [83]. Price 
value could be seen as what consumers sacrifice to obtain whatever they desire. Therefore, the product or service is considered to have value when the cost of obtaining it is relatively less than what consumers get [83]. Therefore, price influences consumer decision making [38].

\subsection{Intention to use the uber application}

Three key variables influence intention, namely attitude, social norms, and perceived behavioural regulation $[33,50]$. This concept represents an incentive for a person to perform a particular behaviour $[3,56,71]$. It may also be viewed as the behavioural determinant and the basis for potential buying decisions [1]. In addition, one should usually act in accordance with his or her intent, except in cases where there are unexpected obstacles, such as a lack of skills, or resources and opportunities [50]. [33] suggests that intention may be used as a behavioural indicator. The intention to use the mobile application was investigated by [72] and it was found that the intention to use it had an effect on the conduct of consumer product adoption.

\section{Theoretical Model and Hypothesis Formulation}

In Figure 1 the following theoretical model is provided based on the literature reviewed. The conceptual model does suggest that perceived convenience, social influence, facilitation conditions, and price value are the predictor variables, while intention to use the Uber application is the outcome application. The available literature highlights several validated works that inform the hypotheses. Such hypotheses emphasise various variable relationships in a way that allows empirical research. The hypotheses are used to allow logical analysis among variables of the relationships. Based on the empirical literature on perceived convenience, facilitation conditions, social influence, price value and intention to use the Uber application, four hypotheses (which are discussed in the following sections) were created.

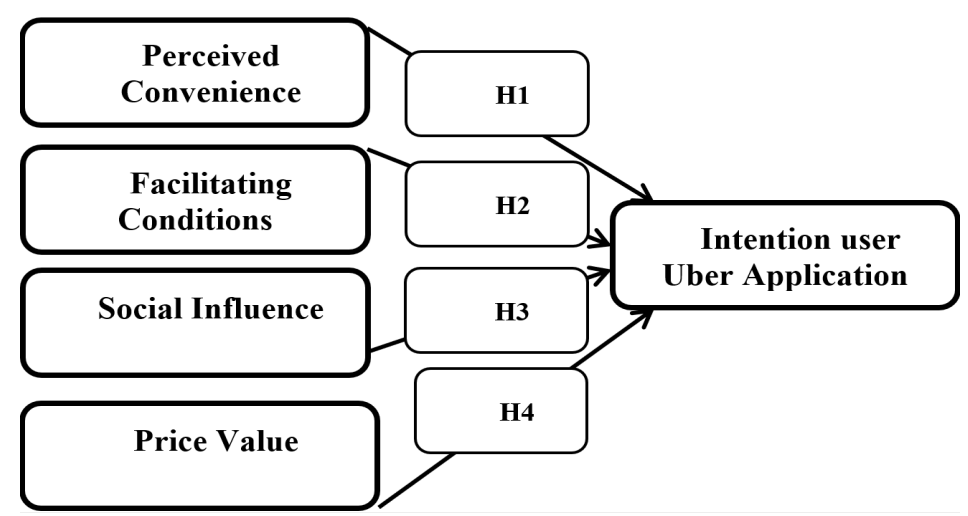

Fig. 1. Theoretical model and hypothesis formulation 


\subsection{Perceived convenience and intention to use the uber application}

It is imperative to discuss the nexus between perceived convenience and intention to use the Uber application. Numerous studies - such as those conducted by [41] - have discovered that convenience is one of the most common factors affecting online consumer purchases. Consequently, online retailers or transportation network companies (such as Uber) need to simplify the online shopping process and try to make the application convenient for users [18]. In addition, [15] found that convenience also had a significant impact on the purpose of shopping online. Their findings coincide with the works of [40], who found positive relationships between perceived convenience and behavioural intention. Thus, this paper hypothesises that:

H1: Perceived convenience has a positive impact on intention to use the Uber application

\subsection{Facilitation conditions and intention to use the uber application}

A study conducted by [2] - which focuses on analysing factors influencing individuals' intentions to utilise social media and the empirical results from [2] showed that facilitation conditions have a positive impact on users' behaviour intention to use social media. In addition, [2]'s findings are in accord with the works of [43], who conducted a study on determinants of fashion mobile application adoption in Sweden. The findings of their research show that facilitation conditions influence fashion application adoption [51]. In addition, [5] explored the effect of fostering factors on the decision to implement e-learning. Results from the [5] study revealed that the decision to use e-learning apps was positively influenced by facilitation conditions. Consequently, we have formulated the following hypotheses:

H2: Facilitation conditions have a positive impact on intention to use the Uber application

\subsection{Social influence and intention to use the uber application}

According to [21] and [81], when it comes to social influence, consumers consider other people's opinions. These people can be referred to as reference groups - for instance, friends, family, peers etc. In a similar vein [2] state that if a person thinks the system is useful, then another person will think it is useful and wish to use the system. The study examining antecedents of e-payment adoption in a developing country (Indonesia), found that social influence positively influences consumer's intentions to use e-payment facilities [38]. In addition, [41] social influence has a strong influence on behavioural intentions. [44] and [69] point out that reference groups can should be taken into consideration by marketers when developing marketing communication campaigns. At times the influence of the social groups can disadvantage the organisation [67] when the social group members are not in favour of the organisation. The study on factors influencing Korean intentions to buy travel tickets online has found that friends influence the purchase decision [41]. Against this background, we propose the following hypothesis: 


\subsection{Price value and intention to use the uber application}

Price value can be classified as an important predictor of how likely it is that a consumer will intend to use the Uber application. Additionally, price is crucial for purchase decisions [36, 56]. Furthermore, [57] emphasised that price certainty changes the intention to utilise mobile shopping applications. In their study, [50] emphasised that, as long as the m-shopping fashion app is useful and enjoyable to use, people are willing to use m-shopping fashion apps without knowing the value of the price. Furthermore, in a conceptual study conducted by [84] (which focuses on deliberating on the variables impacting why consumers will choose Uber over traditional minibuses) established that the price of Uber services influences the intention to select Uber over traditional taxis [83]. Hence it can be hypothesised that:

H4: Price value has a positive impact on intention to use the Uber application

\section{$4 \quad$ Research Design and Methodology}

From the ontological perspective of objectivism of the research, this investigation pursues a positivistic framework as it seeks to discover a link between the variables presented for this analysis and uses measurement instruments for gathering data. Hence, a quantitative approach has been applied as it improves accuracy of findings by statistical analysis. The design was suitable for requesting the information required concerning perceived convenience, facilitation conditions, social influence, price value and intention to use the Uber application. The method also helps one to analyse the causal relationships to the constructs used in the research.

\subsection{Sample and data gathering}

A non-probability sampling approach was used in the present study to collect data from a conveniently chosen sample of 152 participants. [8] and [9] explain that data collection encompasses the physical or electronic collection of data from participants.

\subsection{Questionnaire design}

Based on preceding research, research scales were composed. Appropriate adjustments were made to fit the research context and the objective with a specific end target. The perceived convenience was measured using a scale of four items adapted from [73]. The facilitation conditions were assessed using a scale of three items adapted from [54]. Social influence was measured through the adaptation of [62] scale. A three-item instrument adapted from [82] was used to measure price value. Intention to use an Uber application was measured using a three-item instrument adapted from [82]. All the scales were measured on a five-point Likert-scale and the scale indicators were affixed to a strongly disagree 1) To strongly agree (5) Likert-scale continuum. 


\section{$5 \quad$ Ethical Consideration}

Permission was provided by the research protocol graduate committee of Regenesys Business School, which is located within the Johannesburg metropolitan area. The researchers obtained an ethics clearance certificate from the established business school ethics committee before questionnaires were issued to the respondents. Ethical concern was unconditionally acknowledged and this study was performed in compliance with the ethical standards of academic research, which, among other things, protects the privacy and preferences of the respondents and guarantees the confidentiality of the information provided by the participants.

\section{Data Analysis}

In this analysis, the Social Sciences Statistical Packages (SPSS) were used to analyse data and to determine the causal relationships between the variables. Smart PLS SEM technique was deemed a precise technique to use. Smart PLS has emerged as an important approach to the study of casual models combining multiple constructs $[14,29$, 30]. [30] Argue that Smart PLS is ideal for small-sample analysis. In addition, PLS modelling was carried out to fulfil the dual duty of first, generating relevant model requirements and, second, fitting the already defined model. PLS modelling enquires standardised latent variable scores, since the latter are linear combinations of the indicator variables [22]. The first step in implementing the PLS-SEM algorithm was therefore to normalise the indicator variables in order to have a mean of zero and a standard deviation of one. As a result, on the outer and inner models, the standardised model yielded factor loadings and path coefficients varying between zero and \pm 1 with values closer to one denoting power, respectively.

\subsection{Demographical information of the sample}

$39.5 \%(\mathrm{n}=60)$ of respondents were 60 years of age, followed closely by $30.3 \%$ $(\mathrm{n}=46)$ of respondents $52-59$ years of age, $28.3 \%(\mathrm{n}=43)$ of respondents $44-51$ years of age. $2.0 \%(n=3)$ of the remaining respondents indicated that they were $36-43$ years of age. The majority of respondents $-34.2 \%(\mathrm{n}=52)$ - reported that their highest level of education was basic education. $33.6 \%(\mathrm{n}=51)$ indicated they were degree holders. In addition, $27 \%(\mathrm{n}=41)$ revealed that their highest level of education was postgraduate or equivalent degrees. Moreover, $5.3 \%(\mathrm{n}=8)$ of the respondents revealed that they possess diplomas. Moreover, $3.9 \%(\mathrm{n}=6)$ of the respondents revealed that they were working as general workers. With regard to household income, the majority of respondents $(45.4 \%[\mathrm{n}=69])$ reported having a household income below R5 000 . This was followed by $44.1 \%(\mathrm{n}=67)$ who indicated that they have a household income of R5 001-R10 000. The remainder of the participants $(10.5 \%[\mathrm{n}=16])$ revealed that they have a household income between R10 001 and R15 000. Regarding the respondents ' preferred road transport', it can be pointed out that $55.3 \%(\mathrm{n}=84)$ of the respondents reported that they were using Uber. This was then followed by those who indicated that they make use of 
their personal cars $(25.7$ percent [ $\mathrm{n}=39])$. In addition, $11.8 \%(\mathrm{n}=18)$ revealed that they make use of ordinary taxis. Furthermore, $4.6 \%(\mathrm{n}=7)$ of the respondents revealed that they use buses, while $2.6 \%(n=4)$ of the respondents specified other types of road of transport, for instance, motorbikes and bicycles.

\section{Correlation Analysis}

Correlation was used to explain the intensity of the relation between the variables proposed [36]. The matrix of correlation between the variables was taken up and provided in Table 1.

Table 1. Correlations matrix between constructs

\begin{tabular}{|l|c|c|c|c|c|}
\hline \multicolumn{1}{|c|}{ Research Construct } & $\begin{array}{c}\text { Facilitating } \\
\text { Conditions }\end{array}$ & $\begin{array}{c}\text { Intention to } \\
\text { use an Uber } \\
\text { Application }\end{array}$ & $\begin{array}{c}\text { Perceived } \\
\text { Convenience }\end{array}$ & Price Value & Social Influence \\
\hline Facilitating Conditions & 1 & & & & \\
\hline $\begin{array}{l}\text { Intention to use an Uber } \\
\text { Application }\end{array}$ & 0.675 & 1 & & & \\
\hline Perceived Convenience & 0.653 & 0.693 & 1 & & \\
\hline Price Value & 0.573 & 0.611 & 0.696 & 1 & 1 \\
\hline Social Influence & 0.541 & 0.624 & 0.577 & 0.342 & 1 \\
\hline
\end{tabular}

\section{$8 \quad$ Reliability Analysis}

The reliability results are presented in Table 2 .

Table 2. Accuracy analysis statistics

\begin{tabular}{|c|c|c|c|c|c|}
\hline \multirow{2}{*}{$\begin{array}{l}\text { Research con- } \\
\text { structs }\end{array}$} & \multicolumn{2}{|c|}{ Cronbach's alpha test } & \multirow{2}{*}{$\mathbf{C R}$} & \multirow{2}{*}{ AVE } & \multirow{2}{*}{ Factor loading } \\
\hline & Item-total & Alpha value & & & \\
\hline \multicolumn{6}{|l|}{\begin{tabular}{|l}
$\begin{array}{l}\text { Perceived } \\
\text { Convenience }\end{array}$ \\
\end{tabular}} \\
\hline $\mathrm{PC} 1$ & 0.594 & \multirow{4}{*}{0.733} & \multirow{4}{*}{0.829} & \multirow{4}{*}{0.549} & 0.671 \\
\hline $\mathrm{PC} 2$ & 0.601 & & & & 0.714 \\
\hline PC3 & 0.613 & & & & 0.734 \\
\hline \begin{tabular}{|l|}
$\mathrm{PC} 4$ \\
\end{tabular} & 0.624 & & & & 0.835 \\
\hline \multicolumn{6}{|l|}{\begin{tabular}{|l|} 
Facilitating \\
Conditions \\
\end{tabular}} \\
\hline $\mathrm{FC} 1$ & 0.691 & \multirow{4}{*}{0.868} & \multirow{4}{*}{0.910} & \multirow{4}{*}{0.717} & 0.837 \\
\hline $\mathrm{FC} 2$ & 0.693 & & & & 0.887 \\
\hline FC3 & 0.711 & & & & 0.863 \\
\hline FC4 & 0.713 & & & & 0.797 \\
\hline \multicolumn{6}{|l|}{\begin{tabular}{|l|}
$\begin{array}{l}\text { Social } \\
\text { Influence }\end{array}$ \\
\end{tabular}} \\
\hline SI1 & 0.708 & 0.712 & 0.830 & 0.619 & 0.742 \\
\hline
\end{tabular}




\begin{tabular}{|c|c|c|c|c|c|}
\hline SI2 & 0.712 & & & & 0.825 \\
\hline $\mathrm{S} 13$ & 0.694 & & & & 0.791 \\
\hline \multicolumn{6}{|l|}{$\begin{array}{l}\text { Price } \\
\text { Value }\end{array}$} \\
\hline PV1 & 0.751 & \multirow{3}{*}{0.738} & \multirow{3}{*}{0.852} & \multirow{3}{*}{0.657} & 0.758 \\
\hline PV2 & 0.755 & & & & 0.848 \\
\hline PV3 & 0.757 & & & & 0.824 \\
\hline \multicolumn{6}{|c|}{$\begin{array}{l}\text { Intention to Use } \\
\text { the Uber Appli- } \\
\text { cation }\end{array}$} \\
\hline IUUA1 & 0.696 & \multirow{3}{*}{0.790} & \multirow{3}{*}{0.827} & \multirow{3}{*}{0.619} & 0.809 \\
\hline IUUA2 & 0.714 & & & & 0.882 \\
\hline IUUA3 & 0.721 & & & & 0.651 \\
\hline
\end{tabular}

Note: $\mathrm{CR}=$ composite reliability; $\mathrm{AVE}=$ average variance extracted; a significance level $\mathrm{p}<0.001$; $\mathrm{b}$ significance level $\mathrm{p}<0.01 ; \mathrm{c}$ significance level $\mathrm{p}<0.05$.

The calculation of three different methods, namely Cronbach's alpha reliability test (Cronbach $\alpha$ ), the composite reliability test $(\mathrm{CR})$ and the average variance extracted (AVE) tests, tested the construction reliability of the study measures.

\section{Discriminant Validity}

The study used the matrix of correlation and the average variance extracted (AVE) to assess discriminant validity of the research instruments.

\subsection{Correlation matrix between constructs}

This section conducted an examination of the similarities between the constructs. The statistics on correlation tests were used to explain the presence of a relationship between the constructs, as well as the association's direction and strength [57]. In order to analyse the relationship between perceived ease, enabling circumstances, social influence, price value and the intention to use an Uber, non-parametric correlations were computed. As shown in Table 1, the co-efficient of inter-correlation between latent constructs was less than 1.0, which is consistent with recommendations [60] and [11] and thus provides evidence of discriminatory validity. A strong positive linear association between facilitating conditions and the intention to use Uber at $\mathrm{r}=0.675, \mathrm{p}<0.01$ meaning point, suggests that facilitating conditions affects the intention to use Uber. Additionally, the relationship between perceived convenience and intention to use the Uber application is positive at $\mathrm{r}=0.693 \mathrm{p}<0.01$, and the table shows the positive relationship between price value and intention to use a Uber application at $\mathrm{r}=0.611, \mathrm{p}<0.01$. Moreover, table 1 also shows that there is a positive relationship between the social influence and the purpose of using the Uber application at $\mathrm{r}=0.624, \mathrm{p}<0.01$. 


\section{Partial Least Squares Structural Equation Modelling Approach}

The researchers will quantify the goodness of fit measures with Smart PLS, since it provides the $\mathrm{R}^{2}$ values for the dependent variable. In the current study, intention to use the Uber application is the dependent variable. The fit-goodness has been determined using a global fit-goodness approach [76]. Hence, for this analysis, the following section shows how goodness of fit was measured.

\subsection{Assessment of the goodness of fit}

Overall, $\mathrm{R}^{2}$ in Figure 2 indicates that the model explains $63.2 \%$ of the variance in the endogenous variable for perceived convenience, facilitation conditions, social influence and price value. The global goodness-of-fit statistics for the research model were calculated using the equation, according to formulae given by [77]:

Goodness of fit $=2 \sqrt{(\text { average of all AVEs values* average of all R2) }}$

$=2 \sqrt{2.67 * 0.13}$

$=0.59$

Where AVE represents the average for the study variables of all AVE values and $R^{2}$ represents the average of all $\mathrm{R}^{2}$ values in the complete path model. The estimated global goodness of fit $(\mathrm{GoF})$ is 0.59 , which exceeds the $\mathrm{GoF}>0.36$ threshold indicated by [86]. So, this study concludes that the overall fit of the research model is good.

\subsection{Path model results}

Figure 2 displays the PLS estimation results for the structural model as well as the loadings of items for the study constructs. 


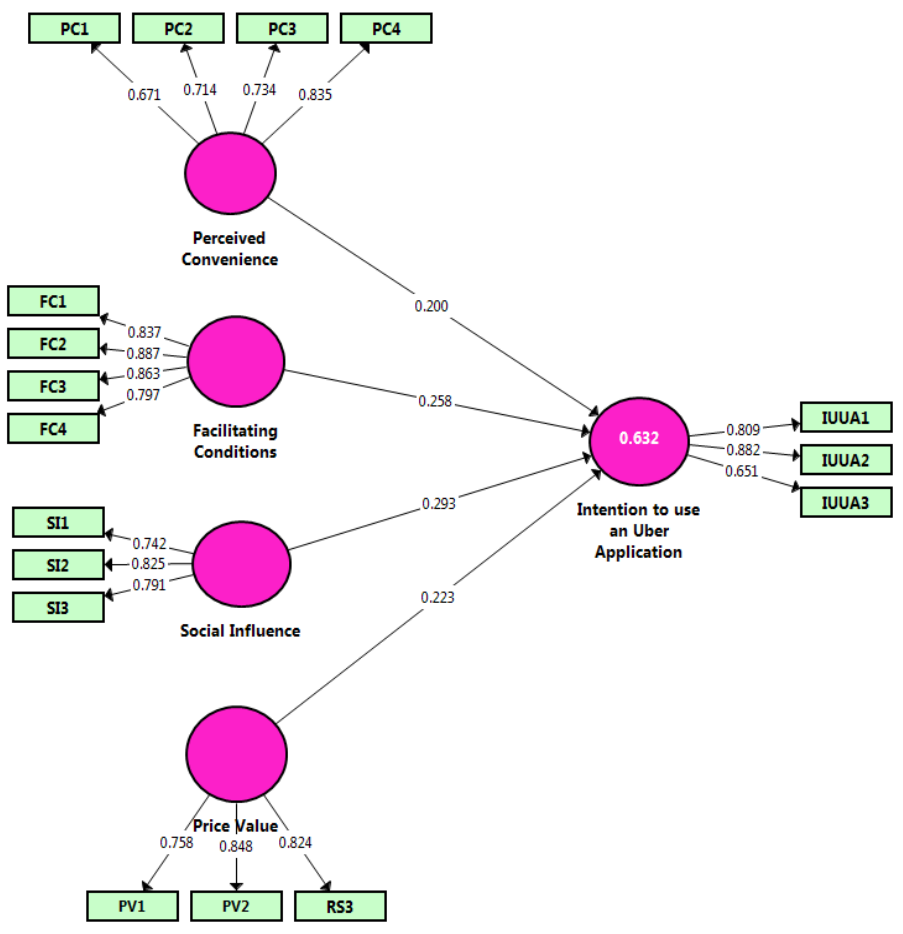

Fig. 2. Path modelling and factor loading results

Table 3. Results of structural equation model analysis

\begin{tabular}{|c|c|c|c|c|}
\hline Path & Hypothesis & Path coefficients $(\beta)$ & T-Statistics & Decision \\
\hline $\mathrm{PC} \rightarrow \mathrm{IUUA}$ & $\mathrm{H} 1(+)$ & 0.200 & 2.457 & Positive and significant \\
\hline $\mathrm{FC} \rightarrow \mathrm{IUUA}$ & $\mathrm{H} 2(+)$ & 0.258 & 3.669 & Positive and significant \\
\hline SI $\rightarrow$ IUUA & $\mathrm{H} 3(+)$ & 0.293 & 3.761 & Positive and significant \\
\hline $\mathrm{PV} \rightarrow$ IUUA & H4 (+) & 0.223 & 3.417 & Positive and significant \\
\hline
\end{tabular}

\section{Testing of the Hypothesis: A Discussion of the Smart PLS Results}

According to [52], data analysis has several benefits, but the most significant is to help organise the findings into micro parts from data gathering sources and macro problem segments. To properly complete this analysis, it is important to evaluate the collected data in order to test the hypotheses proposed. The path coefficient values and tvalues obtained from the bootstrapping algorithm have been tested for hypothesis. According to [73] Path coefficients $(\beta)$ and t-statistics are used for a model to test the relationship between the independent variables and the dependent variable. In other words, how the data endorse the hypothesised model [61] is analysed by the path coefficient and the t-values. 


\subsection{Outcome of hypotheses testing: H1: Perceived convenience have a positive impact on intention to use an uber application}

In Figure 2 and Table 3 it is clear that H1, the relationship between perceived convenience (PC) and the intention to use an Uber application (IUUA), is confirmed by the outcome of the analysis $(\beta=0.200)$ and is relevant at $t$-statistics value of 2.457 . Relationship strength is demonstrated by a coefficient of value of 0.200 . This means that perceived convenience directly affects the intention of the user to use an Uber application in a substantive, significant manner. This finding has ample support from previous empirical research studies, such as [40] which found positive relationships between perceived convenience and behavioural intent. These results are similar to the results of [68], which is that consumers feel the sharing economy is making life more convenient for individuals. The results also agree with [87], which found that convenience affected mobile application adoption. The research [7] conducted on hotel and peer-topeer accommodation user expectations showed that perceived comfort affects the decision to use the Airbnb mobile application.

\subsection{Outcome of hypotheses testing: H2: Facilitating conditions have a positive impact on intention to use the uber application}

In Figure 2 and Table 3, it can be found that $\mathrm{H} 2$, the relationship between facilitation conditions and the intention to use the Uber application, is confirmed by the outcome of the path coefficient value of $(\beta=0.258)$, and is significant as indicated by a t-statistics value of 3.669. Relationship strength is demonstrated by a coefficient of 0.258 . This means that facilitation conditions directly affect the intention to use the Uber application in a constructive, significant manner. The findings of this study also authenticate the presence of a positive relation between the facilitation conditions and the intention to use the Uber application. The results obtained in the present study are not without empirical support either. This result is supported by past literature, which found that facilitating conditions allow consumers to participate in virtual communities [65]. The results of a study evaluating the requirements for boundary-spanning activity in governance networks [80] showed that facilitating conditions affected the adoption of network systems among government employees. Similarly, [79] found that facilitating conditions play a major role in the implementation of inter-organisational seaport information systems. [34]'s study established a relationship between Uber users facilitating the conditions and behavioural intentions. Generally, facilitating conditions influences the adoption of new technology [46].

\subsection{Outcome of hypotheses testing: H3: Social influence has a positive impact on intention to use an uber application}

In Figure 2 and Table 3 it is shown that $\mathrm{H} 4$ strongly supports the relationship between social influence and intention to use the Uber application. The t-statistics are 3.761. Relationship strength is demonstrated by the coefficient of direction of 0.293 . This finding suggests that the price value has a direct positive influence on the purpose of using 
the Uber service. In this study, empirical evidence was also found suggesting a positive association between social influences, which positively impact the decision to use the Uber application. This is in line with [38], who discovered that social influence has a positive effect on electronic payment system intention. Moreover, [43] found that social influence (subjective norms, social factors, and image) has a positive impact on behavioural intent to participate on the website of a political party. The finding coincides with previous results by [61], which confirmed that social influence favourably and significantly affected the restaurants' desire to use mobile apps. The study conducted by [78] on adoption of mobile diet applications revealed that the most important determinant of the intent to use is social influence. Furthermore, [78] it has been identified that social influence often exerts a positive moderating impact on the relationship between hedonic interest and sharing economy purpose.

\subsection{Outcome of hypotheses testing: H4: Price value has a positive impact on intention to use an uber application}

Figure 2 and Table 3 show that $\mathrm{H} 4$ significantly supports the relation between price value and intention to use the Uber application. The t-statistic value is 3.417. Relationship strength is demonstrated by the coefficient of direction of 0.223 . This finding suggests that the price value has a direct positive impact on the purpose of using an Uber car. The study also showed that the price value associated with using the Uber application has been good. This results supported [83]'s empirical study, which focuses on the factors influencing the decision of the consumer to choose an Uber over a traditional taxi. Their paper suggests that perceived price affects customers' intention to use Uber service as opposed to taxi services in tourism destinations [83].

\section{Recommendations}

This research established a close link between perceived convenience and intention to use the Uber mobile application. Therefore. Uber, as a service provider, should strive to enhance the convenience of using the Uber mobile application to influence people to use their application and speed up the adoption of their mobile application. Organisations engaged in a sharing economy should emphasise convenience during system development and ensure that they communicate convenience as a unique selling proposition of their mobile application. With South Africa having the most expensive data in Africa [37], and South Africans spending approximately $25 \%$ of their monthly salary on data [25], Uber could introduce free WiFi hot spots in big cities such as Port Elizabeth, Johannesburg, Durban and Cape Town, which could be used by Uber users to request trips and be made accessible to data-deprived riders. It can be recommended that managers of the Uber application should strive to improve the simplicity and interactivity of the application so that consumers can view the application as convenient.

Given the strong connection between facilitating conditions and intention to use an Uber application (0.258), managers should focus on providing resources and conditions that facilitate the use of the Uber mobile application. In addition, in order to improve 
its performance, continuous efforts should be made to improve the design and functionality of the Uber mobile application. Uber apps can be designed to provide resourceful, helpful and up-to-date information, as well as digital content that meets individual needs or capabilities. In addition to providing convenience passengers, the Uber application's system implementation should also aim to provide and promote functionality and continuance intention. Uber should consider developing a mobile application that is user-friendly to riders with disabilities. They should consider adding features that help enable non-verbal communication between the Uber driver-partner and the rider. Uber should also introduce wheelchair accessible vehicles in South Africa to cater for riders with mobility disabilities. Driver-partners who will be picking up disabled individuals will need training on how to interact and assist their clients. This can be Uber's competitive advantage in South Africa.

Following the rising penetration of South Africa's mobile marketing, improvements in customer use of digital media and technology are key to understanding digital marketing trends [23]. Uber marketing managers therefore need to invest in innovative technologies in order to gain a competitive advantage in the mobile marketing industry - this creates value for customers using Uber taxis as their mode of transportation. Uber's South African marketers will give priority to developing new strategies to keep up with the technology developments as the mobile platform evolves on a regular basis $[23,52]$. Innovation includes marketing campaigns featuring new or cutting-edge strategies or innovations to promote a company or product [21]. Marketers need to ensure that their marketing campaigns exploit new, innovative as well as imaginative implementation of proven technology [52]. A good strategy involving technology that can be applied to young consumers is location-based; any marketing campaign uses locationbased services as the primary anchor of the campaign to communicate with customers and deliver highly relevant, personalised messages at a time and place when consumers are most likely to act on them [62]. As a result of the open-ended nature of technology, marketers are posed with no limits in the generation of their ideas.

Uber managers can provide incentives or bonus points to existing users of the Uber mobile application to recommend the use of Uber to their friends. In doing so, current Uber mobile application users will persuade their peers to follow their example. This will give impetus to social influence, culminating in improved behavioural intention towards the use of the Uber mobile application.

\section{Limitations and Opportunities for Future Research}

As with all studies, this analysis, which opens up doors for further research, has several limitations. The first constraint is the current research background. The research background for this analysis is a developing country (South Africa). If applied to other contexts, the analysis may produce different results. However, the population of the study was small, as it included only consumers within Johannesburg, a city in South Africa. That restricts the probability of generalising the findings to include all South African consumers. Therefore, the study results may only be applicable to customers in 
the Johannesburg region. Secondly, the sample size was set to 152 consumers. For future research, a larger sample size could be used, and may produce more interesting results. Third, the research model's predictability could have been improved if more independent variables were included in the research model to affect the behavioural intent to use the Uber application. Therefore, this study focused only on four antecedents, viewed as perceived convenience, facilitating conditions, social influence and price value. Digital marketing academics should examine other factors instrumental in stimulating the intention to use the Uber application, such as perceived risk, the need for reputation and the immediate need for service. Eventually, since this research focuses on the decision to use the Uber application, potential researchers can extend the analysis by researching the determinants of the Uber application's actual usage.

\section{Conclusion}

Keywords were included in the current study, key questions and theoretical objectives were identified, and a literature review was undertaken to gain an overview or a deeper understanding of the concepts. The research does authenticate that variables such as perceived convenience, social influence, facilitating conditions, and price value are influential in enhancing the intention of using Uber. This research explores theoretical and organisational consequences. In theory, this study makes substantial advances in marketing strategy theory and consumer behaviour by methodologically examining the interplay between perceived convenience, social influence, facilitating conditions and price value on the decision to use the Uber application. Therefore, this study makes a significant contribution to the body of knowledge. In practical terms, perceived convenience, facilitating conditions, social influence and price value were exerted as having a favourable effect on the intention to adopt the Uber application; improvements in each of these four factors may stimulate intention to use the Uber application among consumers in Johannesburg, which is located in the Gauteng province of South Africa. Perceived value can be taken into account by making sure customers can afford the Uber fares. Uber's marketing professionals can use the demographic profile of the customers who participated in this survey to learn consumers ' affordability in terms of household income. Doing these things in a more refined manner will certainly lead to the Uber application being of good service.

\section{References}

[1] Ajzen, I. (1991). The theory of planned behavior. Organizational Behavior and Human Decision Processes, 50(2): 179-211. https://doi.org/10.1016/0749-5978(91)90020-t

[2] Akar, E., \& Mardikyan, S. (2014). Analyzing factors affecting users' behavior intention to use social media: Twitter case. International Journal of Business and Social Science, 5(11): 12-32.

[3] Armitage, C. J. \& Conner, M. (2001). Efficacy of the Theory of Planned Behavior: A metaanalytic Review. British Journal of Social Psychology, 40: 471-499. 
[4] Bakar, A. A., \& Razak, F. Z. B. A. (2014). The role of facilitating condition and social influence towards continuance intention to use E-learning. International Journal of Technical Research and Applications, 2(1), 12-14.

[5] Beneke, J., \& Blampied, S. (2012, September). Driving consumer perceptions through Facebook: an investigation into empowering brands. The $21^{\text {st }}$ Century Conference, September 1-5, 2012, pp. 40-47,

[6] Berndt, A. \& Petzer, D. 2011. Marketing research. Cape Town: Pearson Education.

[7] Birinci, H., Berezina, K., \& Cobanoglu, C. (2018). Comparing customer perceptions of hotel and peer-to-peer accommodation advantages and disadvantages. International Journal of Contemporary Hospitality Management, 30(2): 1190-1210. https://doi.org/10.1108/ ijchm-09-2016-0506

[8] Blumberg, B., Cooper, D. R. \& Schindler, P. S. (2008). Business research methods. 2nd ed. Berkshire: McGraw-Hill.

[9] Bryman, A. \& Bell, E. (2011). Business research methods. $3^{\text {rd }}$ ed. New York: Oxford University Press.

[10] Chang, C. C., Tseng, K. H., Liang, C., \& Yan, C. F. (2013). The influence of perceived convenience and curiosity on continuance intention in mobile English learning for high school students using PDAs. Technology, Pedagogy and Education, 22(3): 373-386. https://doi.org/10.1080/1475939x.2013.802991

[11] Chang, C. C., Yan, C. F., \& Tseng, J. S. (2012). Perceived convenience in an extended technology acceptance model: Mobile technology and English learning for college students. Australasian Journal of Educational Technology, 28(5): 809-826. https://doi.org/10. $14742 /$ ajet.818

[12] Chau, P. Y., \& Hu, P. J. H. (2002). Investigating healthcare professionals' decisions to accept telemedicine technology: an empirical test of competing theories. Information \& management, 39(4): 297-311. https://doi.org/10.1016/s0378-7206(01)00098-2

[13] Chinomona, E., \& Maziriri E. T. (2017). The influence of brand trust, brand familiarity and brand experience on brand attachment: a case of consumers in the Gauteng province of South Africa. Journal of Economics and Behavioral Studies, 9(1): 69-81. https://doi.org/10.22610/ jebs.v9i1(j). 1558

[14] Cho, Y. C., \& Sagynov, E. (2015). Exploring factors that affect usefulness, ease of use, trust, and purchase intention in the online environment. International Journal of Management \& Information Systems, 19(1): 21-36. https://doi.org/10.19030/ijmis.v19i1.9086

[15] Cohen, S. S. (1998). Guide to the Polyamines. Oxford University Press.

[16] Cooper, A. (2016). Staying safe with strangers. Life Tech. Sunday Independent, 18(09): 110.

[17] Delafrooz, N., Paim, L. H. \& Khatibi, A. (2011). Understanding consumer's internet purchase intention in Malaysia. African Journal of Business Management, 5(7): 2837-2846

[18] Dictionary, O. E. (2016). Oxford English Dictionary online.

[19] Djsbubreakfastshow, (2015). Uber plans to create 15, 000 jobs in SA by 2018. Available at: http://djsbubreakfast.com/. [ Accessed 12 May 2017].

[20] Dlodlo, N. (2017). Re-thinking a structural model for m-phone paying among South African consumers. Journal of Economics and Behavioral Studies, 9(2): 114130.https://doi.org/10.22610/jebs.v9i2.1655

[21] Dondolo, B. H. \& Madinga, N. W. (2017). Consuming for recognition: South African youth consumption of status clothing. The Journal of Applied Business Research, 33(5): 919928.https://doi.org/10.19030/jabr.v33i5.10015 
[22] Donga, G. T (2017). Consumer acceptance of mobile marketing through mobile phones: a case study of South African university students. Master of Commerce in Business Management dissertation. University of Venda. https://doi.org/10.3923/itj.2018.1.10

[23] Dube, S.C. (2015). Uber: a game-changer in passenger transport in South Africa? The CCRED Quarterly Review, 4-6.

[24] Eye for Travel. (2015). Uber in South Africa: great for riders, what about the drivers"' Retrieved from: http://www.eyefortravel.cm/. [Accessed 12 May 2017].

[25] Eye Witness News. (2017). How much do South African spend on data? Available at: https://ewn.co.za/2017/03/06/africa-check-how-much-do-south-africans-spendon-data [Accessed on 12/01/2020]. https://doi.org/10.1787/f19e803c-en

[26] Ferris, G. R., Perrewé, P. L., Daniels, S. R., Lawong, D., \& Holmes, J. J. (2017). Social influence and politics in organizational research: What we know and what we need to know. Journal of Leadership \& Organizational Studies, 24(1): 5-19. https://doi.org/10.1177/ $\underline{1548051816656003}$

[27] Gupta, S., \& Kim, H. W. (2007). The moderating effect of transaction experience on the decision calculus in on-line repurchase. International Journal of Electronic Commerce, 12(1): 127-158. https://doi.org/10.2753/jec1086-4415120105

[28] Hair, J. F., Ringle, C. M., \& Sarstedt, M. (2011). PLS-SEM: indeed, a silver bullet. Journal of Marketing Theory and Practice, 19(2): 139-152. https://doi.org/10.2753/mtp10696679190202

[29] Hair, J.F., Ringle, C.M. \& Sarstedt, M. (2013). Editorial-partial least squares structural equation modelling: Rigorous applications, better results and higher acceptance. Long Range Planning, 46(1-2): 1-12. https://doi.org/10.1016/j.lrp.2013.01.001

[30] Henama, U. S., \& Sifolo, P. P. S. (2017). Uber: The South Africa experience. African Journal of Hospitality, Tourism and Leisure, 6(2): 1-10.

[31] Henama, U.S. (2016). Uber is coming Express Newspaper'. Available at: http://www.news24.com/SouthAfrica/Local/Express-News/uber-is-coming. [Accessed 12 May 2017].

[32] Holst, A., \& Iversen, J. M. (2011). An application of a revised Theory of Planned Behavior: predicting the intention to use personal care products without endocrine disrupting chemical Available at: http://studenttheses.cbs.dk/bitstream/handle/10417/3137/anne_hols_og_julie_maria_iversen.pdf sequence $=1$. [Assessed date 12/01/2018]

[33] Hsiao, C. H. \& Tang, K. Y. (2014). Explaining undergraduates' behaviour intention of etextbook. Library Hi Tech, 32(1): 139-163. https://doi.org/10.1108/lht-09-2013-0126

[34] Indrawati, I. (2017). Analysis of user acceptance towards online transportation technology using UTAUT 2 model: a case study in Uber, Grab and Go-Jek in Indonesia. International Journal of Science and Research, 6(7): 1479-1482. https://doi.org/10.21275/art20175426

[35] Jaafar, S. N., Lalp, P. E., \& Naba, M. M. (2012). Consumers' perceptions, attitudes and purchase intention towards private label food products in Malaysia. Asian Journal of Business and Management Sciences, 2(8): 73-90.

[36] Junadi, S. (2015). A model of factors influencing consumer's intention to use e-payment system in Indonesia. Procedia Computer Science, 59: 214-220. https://doi.org/10.1016/ i.procs.2015.07.557

[37] Kahla, C. (2019). South Africa has the most expensive internet. Available at: https://www.thesouthafrican.com/tech/south-africa-most-expensive-internet-infographic/ [Accessed on 12/01/2020].

[38] Kalpana, R., \& Shibu, N. S (2016). Influence of Few Variables on Consumer Buying Behaviour, International Journal of Management, 7(7): 387-394. 
[39] Khan, S. A., Liang, Y., \& Shahzad, S. (2015). An empirical study of perceived factors affecting customer satisfaction to re-purchase intention in online stores in China. Journal of Service Science and Management, 8(3): 291-305. https://doi.org/10.4236/jssm.2015.83032

[40] Khatibi A, Haque, A., \& Karim, K. (2006). E-commerce: a study on internet shopping in Malaysia. Journal of Applied Sciences, 6(1): 696-705.

[41] Lee, H. Y., Qu, H., \& Kim, Y. S. (2007). A study of the impact of personal innovativeness on online travel shopping behavior: a case study of Korean travellers. Tourism Management, 28(3): 886-897. https://doi.org/10.1016/j.tourman.2006.04.013

[42] Lewis, J. (2014). Factors That Influence behavioral intention on political party websites in South Africa. Master of Commerce in Information Systems dissertation. University of Cape Town.

[43] Limayem, M., Khalifa, M., \& Chin, W. W. (2004). Factors motivating software piracy: a longitudinal study. IEEE transactions on engineering management, 51(4): 414-425. https://doi.org/10.1109/tem.2004.835087

[44] Madinga, N. W. \& Dondolo, B. H. (2017). The role of reference group on consumer purchasing behavior: a literature review. The $29^{\text {th }}$ Conference of the Southern African Institute of Management Scientists (SAIMS), Bloemfontein, South Africa.

[45] Maduku, D. K. (2015). An empirical investigation of students' behavioural intention to use e-books. Journal of the Southern African Institute for Management Scientists, 24(3): 3-20.

[46] Mahardika, H., Thomas, D., Ewing, M. T. \& Japutra, A. (2019). Experience and facilitating conditions as impediments to consumers' new technology adoption. The International Review of Retail, Distribution and Consumer Research, 29(1): 79-98. https://doi.org/10.1080/ $\underline{09593969.2018 .1556181}$

[47] Makelane, H., \& Mathekga, J. (2017). Radical innovation, Uber-hailing transport and its impact: a case study of Uber business in Cape Town, South Africa. International Journal of Advanced research, 5(10): 1559-1566. https://doi.org/10.21474/ijar01/5672

[48] Malhotra, N. K. (2010). Marketing research: an applied orientation. $6^{\text {th }}$ ed. Eaglewood Cliffs: Prentice Hall.

[49] Mhlophe, J. B. (2015). Antecedents of consumer purchase intentions towards organic food produces: a case study of the Johannesburg municipality Master's in the School of Economic and Business Sciences - Marketing, University of the Witwatersrand, Johannesburg.

[50] Miladinovic, J., \& Xiang, H. (2016). A study on factors affecting the behavioral intention to use mobile shopping fashion apps in Sweden. Bachelor's Thesis in Business Administration. International Business School, Jonkoping University.

[51] Mobile Marketing Association. 2017. Community mobile. Available at: http://www.business2community.com/mobile. [Accessed on 9 November 2017].

[52] Mohabier, R. (2016). The application of a social networking learning tool in a primary school within South Africa. Master of Business Administration Dissertation, Regenesys Business School. Sandton. South Africa.

[53] Moore, G. C., \& Benbasat, I. (1991). Development of an instrument to measure the perceptions of adopting an information technology innovation. Information systems research, 2(3): 192-222. https://doi.org/10.1287/isre.2.3.192

[54] Munshi, R. (2016). 101: Uber in SA. Financial Mail. Available at: http://www.financialmail.co.za/fmfox/2016/05/91/101-uber-in-sa/. [Accessed 12 May 2017].

[55] Munusamy, J., \& Wong, C. H. (2008). Relationship between marketing mix strategy and consumer motive: an empirical study in major Tesco stores. Unitar e-journal, 4(2): 41-56. 
[56] Mushwana, J. T. (2017). Antecedents that influence Johannesburg customers' intention to use Transportation Network Companies (TNCs): perspectives on the Uber mobile application. Master of Business Administration. Regenesys Business School, Sandton. South Africa.

[57] Natarajan, T., Balasubramanian, S. A. \& Kasilingam, D. L. (2017). Understanding the intention to use mobile shopping applications and its influence on price sensitivity. Journal of Retailing and Consumer Services, 37(1): 8-22.https://doi.org/10.1016/j.jretconser. $\underline{2017.02 .010}$

[58] Niemand, C. J., \& Chauke, H. (2017). The use of mobile applications by public transport commuters in Gauteng, South Africa. South African Journal of Information Management, 19(1): 1-9. https://doi.org/10.4102/sajim.v19i1.782

[59] Nunnally, J. C. (1978). Psychometric theory. New York: McGraw-Hill.

[60] Nysveen, H., Pedersen, P. E., \& Thorbjørnsen, H. (2005). Explaining intention to use mobile chat services: moderating effects of gender. Journal of consumer Marketing, 22(5): 247-256. https://doi.org/10.1108/07363760510611671

[61] Palau-Saumell, R., Forgas-Coll, S., Sanchez-Garcia, J. \& Robress, E. (2019). User acceptance of mobile apps for restaurants: an expanded and extended UTAUT-2. Sustainability, 11(1): 1-24. https://doi.org/10.3390/su11041210

[62] Papadakis, S. T., \& Kalogiannakis, M. (2017). Mobile educational applications for children. What educators and parents need to know? International Journal of Mobile Learning and Organization, 11(3), 256-277. https://doi.org/10.1504/ijmlo.2017.085338

[63] Papadakis, S. (2018). Evaluating pre-service teachers' acceptance of mobile devices with regards to their age and gender: a case study in Greece. International Journal of Mobile Learning and Organisation, 12(4), 336-352. https://doi.org/10.1504/ijmlo.2018.095130

[64] Papadakis, S., Zaranis, N., \& Kalogiannakis, M. (2019). Parental involvement and attitudes towards young Greek children's mobile usage. International Journal of Child-Computer Interaction, 22, 100-144. https://doi.org/10.1016/j.ijcci.2019.100144

[65] Penarroja, V., Sanchez, J., Gamero, N., Orengo, V., \& Zornoza, A. M. (2019). The influence of organizational facilitating conditions and technology acceptance factors on the effectiveness of virtual communities of practice. Behavior \& Information Technology, 38(8): 845857. https://doi.org/10.1080/0144929x.2018.1564070

[66] Persuad, A. \& Azhar, I. (2012). Innovative mobile marketing practice. Are consumers ready? Journal of Marketing Practice: Applied Marketing Science, 30(2): 418-444. https://doi.org/10.1108/02634501211231883

[67] Phakathi, B. (2016). Uber to experiment with cash payments"'. Business Day. Available at: http://www.bdlive.co.za/national/transport/. [Accessed on 12 May 2017].

[68] PWC. (2015). The sharing economy: consumer intelligence series. Available at: https://www.eurofound.europa.eu/data/platform-economy/records/the-sharing-economyconsumer-intelligence-series [Accessed on 12/01/2019].

[69] Rana, S. S., Osman, A. \& Othman, Y. H. (2015). Factors Affecting Purchase Intention of Customers to Shop at Hypermarkets. Mediterranean Journal of Social Sciences, 6(3): 429457. https://doi.org/10.5901/mjss.2015.v6n3p429

[70] Rayle, L., Dai, D., Chan, N., Cervero, R., \& Shabeen, S. (2016). Just a better taxi? A surveybased comparison of taxis, transit and ride sourcing services in San Francisco. Transport Policy, 45: 168-178. https://doi.org/10.1016/j.tranpol.2015.10.004

[71] Shange, N. A. (2017). Is the public transport system failing the poor: A critical analysis of the South African Public Transport System? Case Study of Johannesburg. Doctoral dissertation, Palacký University Olomouc. 
[72] Shanmugam, A., Savarimuthu, M. T., \& Wen, T. C. (2014). Factors affecting Malaysian behavioral intention to use mobile banking with mediating effects of attitude. Academic Research International, 5(2): 236-253.

[73] Subramaniama, C., Shamsudinb, F. M., \& Alshuaibic, A. S. I. (2017). Investigating employee perceptions of workplace safety and safety compliance using PLS-SEM among technical employees in Malaysia. Journal of Applied Structural Equation Modeling, 1(1): 4461.

[74] Suki, N. M., \& Suki, N. M. (2011). Exploring the relationship between perceived usefulness, perceived ease of use, perceived enjoyment, attitude and subscribers' intention towards using $3 \mathrm{G}$ mobile services. Journal of Information Technology Management, 22(1): 1-7.

[75] Tenenhaus, M., Amato, S., \& Esposito Vinzi, V. (2004). A global goodness-of-fit index for PLS structural equation modelling. In Proceedings of the XLII SIS Scientific Meeting, 1: 739-742.

[76] Tenenhaus, M., Vinzi, V. E., Chatelin, Y. M., \& Lauro, C. (2005). PLS path modelling. Computational statistics \& data analysis, 48(1): 159-205. https://doi.org/10.1016/ j.csda.2004.03.005

[77] Thaler, R. H., \& Tucker, W. (2013). Smarter information, smarter consumers. Harvard Business Review, 91(1): 44-54.

[78] Tsou, H., Chen, J., Chou, C. Y., \& Chen, T. 2019. Sharing economy service experience and its effects on behavioral intention. Sustainability, 11(1): 1-25. https://doi.org/10.3390/ $\underline{\text { su} 11185050}$

[79] Vairetti, C., Gonzalez-Ramirez, R. G., Maldonado, S., Alvarez, C. \& Vob, S. (2019). Facilitating conditions for successful adoption of inter-organizational information systems in seaports. Transportation Research Part A, 130(1): 333-350.https://doi.org/10.1016/ j.tra.2019.09.017

[80] Van Meerkerk, I. \& Edelenbos, J. (2018). Facilitating conditions for boundary-spanning behavior in governance networks. Public Management Review, 20(5): 503524.https://doi.org/10.1080/14719037.2017.1302248

[81] Van Schalkwyk, P., Maziriri, E. T. \& Mokoena. B. A. (2017). Refinement and validation of scales for measuring perceived social risk, buying behaviour and retail store choice. International Journal of Business and Management Studies, 9(2): 12-34.

[82] Venkatesh, V., Morris, M. G., Davis, G. B., \& Davis, F. D. (2003). User acceptance of information technology: toward a unified view. MIS quarterly, 425-478 https://doi.org/10. $\underline{2307 / 30036540}$

[83] Venkatesh, V., Thong, J. \& Xu, X. (2012). Consumer acceptance and use of information technology: extending the unified theory of acceptance and use of technology. MIS Quarterly, 36(1): 157-178. https://doi.org/10.2307/41410412

[84] Wan, W. N. A. A. B., Mohamad, A. F. M. F., Shahib, N. S., Azmi, A., Kamal, S. B. M. \& Abdullah, D.A. (2016). Framework of customer's intention to use Uber service in tourism destination. International Academic Research Journal of Business and Technology, 2(2): 102-106.

[85] Weatherhead, E. (2014). An integrated approach to analyzing (adaptive) management using the politicized. IAD framework. Ecology and Society, 19(1): 1-13. https://doi.org/10.5751/ es-06177-190110

[86] Wetzels, M., Odekerken-Schröder, G., \& Van Oppen, C. (2009). Using PLS path modeling for assessing hierarchical construct models: Guidelines and empirical illustration. MIS quarterly, 177-195. https://doi.org/10.2307/20650284 
[87] Zhu, G., So, K. K. F. \& Hudson, S. (2017). Inside the sharing economy: understanding consumer motivations behind the adoption of mobile applications. International Journal of Contemporary Hospitality Management, 29(9): 2218- 2239. https://doi.org/10.1108/ijchm-09$\underline{2016-0496}$

\section{Authors}

Dr. Eugine Tafadzwa Maziriri is currently a Senior Lecturer in the Department of Business Management at University of the Free State in Bloemfontein, South Africa. He teaches marketing courses to under-graduate and post-graduate students. He has a keen interest in consumer behaviour, green marketing and the development of small businesses. In addition, he has published numerous papers in peer-reviewed, international and local accredited journals. He has presented in local and international conferences. He earned his PhD in Business Sciences (Marketing) from the University of the Witwatersrand, Johannesburg, South Africa. Email: maziririet@ufs.ac.za

Dr. Miston Mapuranga is a holder of a Ph.D. in Management of Technology and Innovation at the Da Vinci Institute for Technology Management, Johannesburg, South Africa. Dr Mapuranga has published a number of research articles in international scientific accredited journals.

Mr. Justice Mushwana is an emerging researcher as well as an MBA graduate from the Regenesys Business School, Johannesburg, South Africa.

Mr. Nkosivile Welcome Madinga is currently a doctoral candidate for the Ph.D. in Marketing at Nelson Mandela University in Port Elizabeth, South Africa. He works as a lecturer within the Marketing Section, at the University of Cape Town. He has published several journal articles and has presented papers at national conferences.

Article submitted 2019-04-08. Resubmitted 2020-01-24. Final acceptance 2020-01-25. Final version published as submitted by the authors. 